Prepared in cooperation with the

Maryland Department of the Environment

\title{
Incorporation of Water-Use Summaries into the StreamStats Web Application for Maryland
}

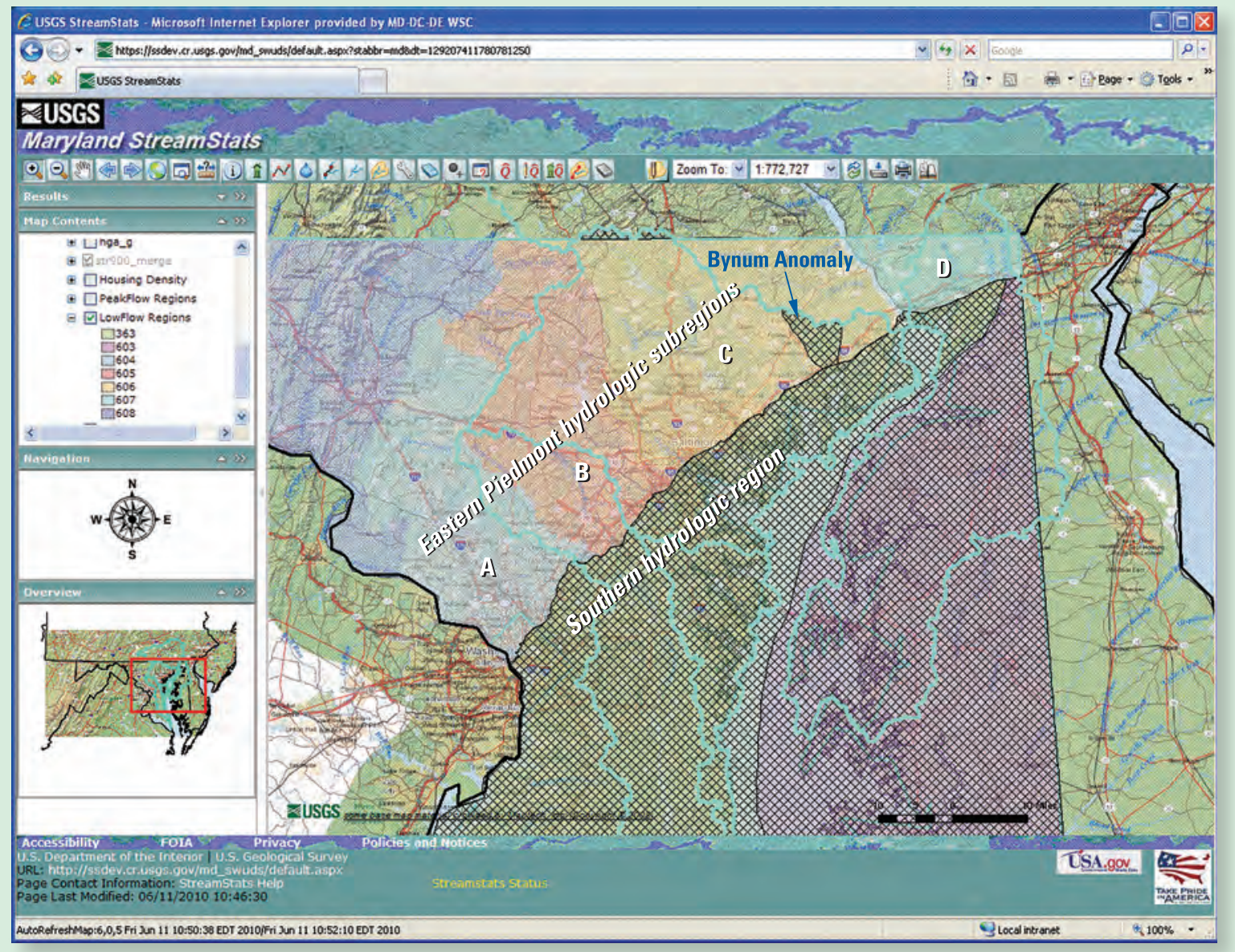

Scientific Investigations Report 2010-5111 
Cover. View of the StreamStats user interface for Maryland. 


\section{Incorporation of Water-Use Summaries into the StreamStats Web Application for Maryland}

By Kernell G. Ries III, Marilee A. Horn, Mark R. Nardi, and Steven Tessler

Prepared in cooperation with the

Maryland Department of the Environment

Scientific Investigations Report 2010-5111 


\section{U.S. Department of the Interior \\ KEN SALAZAR, Secretary \\ U.S. Geological Survey \\ Marcia K. McNutt, Director}

U.S. Geological Survey, Reston, Virginia: 2010

For more information on the USGS - the Federal source for science about the Earth, its natural and living resources, natural hazards, and the environment, visit http://www.usgs.gov or call 1-888-ASK-USGS

For an overview of USGS information products, including maps, imagery, and publications, visit http://www.usgs.gov/pubprod

To order this and other USGS information products, visit http://store.usgs.gov

Any use of trade, product, or firm names is for descriptive purposes only and does not imply endorsement by the U.S. Government.

Although this report is in the public domain, permission must be secured from the individual copyright owners to reproduce any copyrighted materials contained within this report.

Suggested citation:

Ries, K.G., III, Horn, M.A., Nardi, M.R., and Tessler, S., 2010, Incorporation of water-use summaries into the StreamStats web application for Maryland: U.S. Geological Survey Scientific Investigations Report 2010-5111, 18 p. 


\section{Contents}

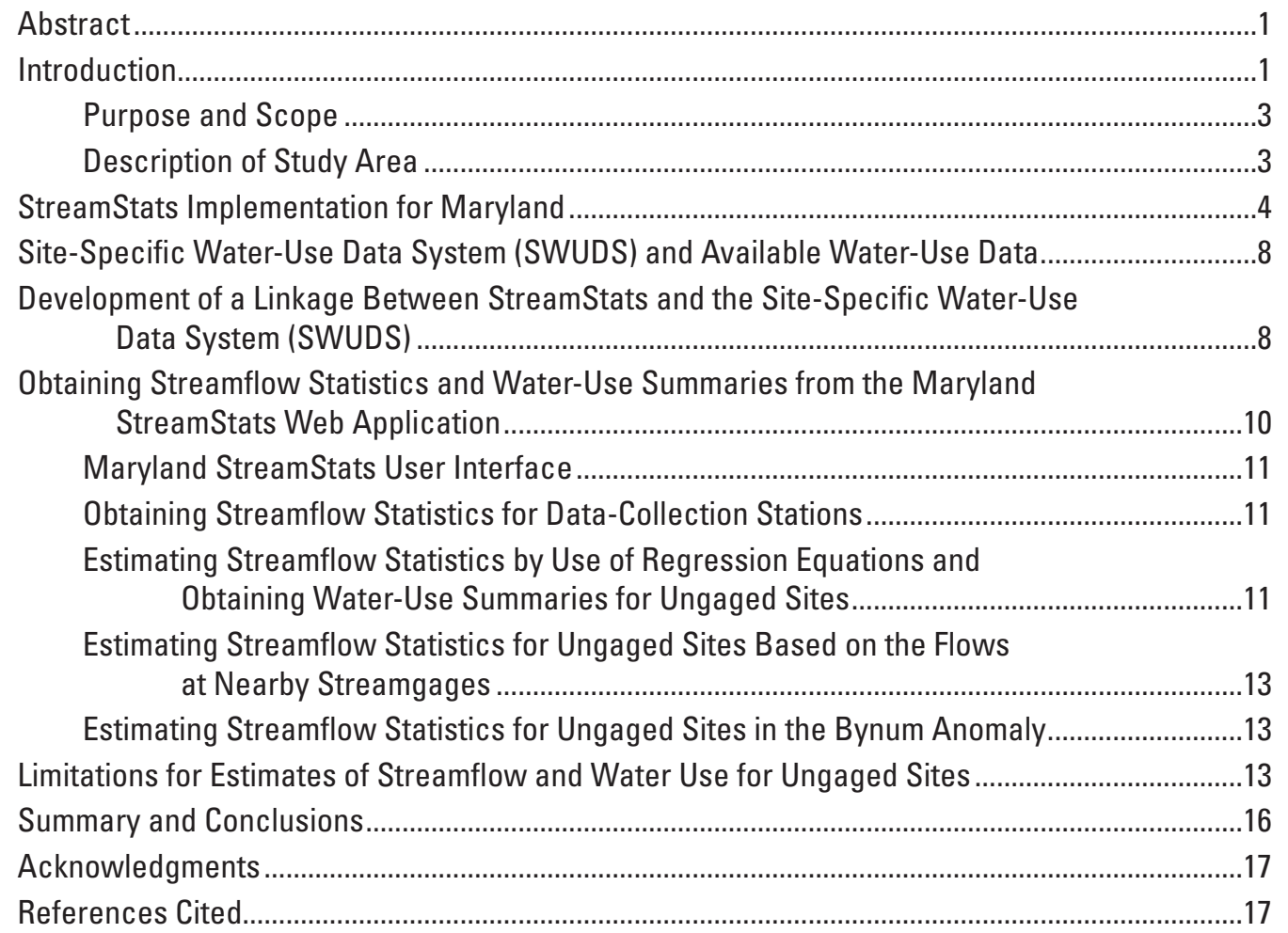




\section{Figures}

1. Map showing location of areas affected by Base Realignment and Closure (BRAC) activities in Maryland, including Aberdeen Proving Ground and Fort Meade..

2. View of the StreamStats user interface for Maryland with aqua lines showing the hydrologic accounting units in which the application is implemented and colored areas corresponding to the low-flow hydrologic regions of Carpenter and Hayes (1996).

3. An example of modeling conveyance-based water-use data in the Site-Specific Water-Use Data System (SWUDS) showing 22 sites and 23 numbered conveyances

4. Data and databases used in construction of the Maryland Site-

Specific Water-Use Data System (SWUDS) conveyance database.

5. The StreamStats link frame that appears on each Web page.

6. Map showing example watershed delineation (black and yellow line) for an ungaged site in Maryland StreamStats, showing upstream datacollection stations (triangles), water withdrawals (small orange dots), and water discharge locations (small blue dots).

7. Example water-use summary report for the ungaged site shown in figure 6

\section{Tables}

1. Peak-flow regression equations for the Piedmont and Western Coastal Plain in Maryland.

2. Low-flow regression equations for subregions $A$ through $D$ in the Eastern Piedmont in Maryland

3. Previously published streamflow statistics for streamgages and low-flow partial-record stations, and average values in the Bynum Anomaly area of Piedmont subregion C 


\section{Conversion Factors}

\begin{tabular}{|c|c|c|}
\hline Multiply & By & To obtain \\
\hline \multicolumn{3}{|c|}{ Length } \\
\hline foot (ft) & 0.3048 & meter $(\mathrm{m})$ \\
\hline mile $(\mathrm{mi})$ & 1.609 & kilometer (km) \\
\hline \multicolumn{3}{|c|}{ Area } \\
\hline square mile $\left(\mathrm{mi}^{2}\right)$ & 2.590 & square kilometer $\left(\mathrm{km}^{2}\right)$ \\
\hline \multicolumn{3}{|c|}{ Volume } \\
\hline gallon (gal) & 3.785 & liter (L) \\
\hline gallon (gal) & 0.003785 & cubic meter $\left(\mathrm{m}^{3}\right)$ \\
\hline gallon (gal) & 3.785 & cubic decimeter $\left(\mathrm{dm}^{3}\right)$ \\
\hline million gallons (Mgal) & 3,785 & cubic meter $\left(\mathrm{m}^{3}\right)$ \\
\hline cubic foot $\left(\mathrm{ft}^{3}\right)$ & 28.32 & cubic decimeter $\left(\mathrm{dm}^{3}\right)$ \\
\hline cubic foot $\left(\mathrm{ft}^{3}\right)$ & 0.02832 & cubic meter $\left(\mathrm{m}^{3}\right)$ \\
\hline \multicolumn{3}{|c|}{ Flow rate } \\
\hline cubic foot per second $\left(\mathrm{ft}^{3} / \mathrm{s}\right)$ & 0.02832 & cubic meter per second $\left(\mathrm{m}^{3} / \mathrm{s}\right)$ \\
\hline $\begin{array}{l}\text { cubic foot per second per square } \\
\text { mile }\left[\left(\mathrm{ft}^{3} / \mathrm{s}\right) / \mathrm{mi}^{2}\right]\end{array}$ & 0.01093 & $\begin{array}{l}\text { cubic meter per second per square kilometer } \\
{\left[\left(\mathrm{m}^{3} / \mathrm{s}\right) / \mathrm{km}^{2}\right]}\end{array}$ \\
\hline million gallons per day (Mgal/d) & 0.04381 & cubic meter per second $\left(\mathrm{m}^{3} / \mathrm{s}\right)$ \\
\hline
\end{tabular}

\section{Abbreviations and Acronyms}

APG

BRAC

DEM

DoD

ESRI

Fort Meade

GIS

HUC

ID

LFPR

MCD

MDE

NLCD

NSA

SWUDS

USGS

WMA
Aberdeen Proving Ground

Federal Base Realignment and Closure process

Digital Elevation Model

U.S. Department of Defense

Environmental Systems Research Institute, Inc.

Fort George G. Meade

Geographic Information System

Hydrologic Unit Code accounting unit

Identification number or name

Low-flow partial-record

U.S. Census Bureau Minor Civil Division

Maryland Department of the Environment

National Land Cover Database of 2001

U.S. National Security Agency

U.S. Geological Survey Site-Specific Water-Use Database System

U.S. Geological Survey

Maryland Department of the Environment, Water Management Administration 



\title{
Incorporation of Water-Use Summaries into the StreamStats Web Application for Maryland
}

\author{
By Kernell G. Ries III, Marilee A. Horn, Mark R. Nardi, and Steven Tessler
}

\section{Abstract}

Approximately 25,000 new households and thousands of new jobs will be established in an area that extends from southwest to northeast of Baltimore, Maryland, as a result of the Federal Base Realignment and Closure (BRAC) process, with consequent new demands on the water resources of the area. The U.S. Geological Survey, in cooperation with the Maryland Department of the Environment, has extended the area of implementation and added functionality to an existing map-based Web application named StreamStats to provide an improved tool for planning and managing the water resources in the BRAC-affected areas. StreamStats previously was implemented for only a small area surrounding Baltimore, Maryland, and it was extended to cover all BRAC-affected areas.

StreamStats could provide previously published streamflow statistics, such as the 1-percent probability flood and the 7-day, 10-year low flow, for U.S. Geological Survey data-collection stations and estimates of streamflow statistics for any user-selected point on a stream within the implemented area. The application was modified for this study to also provide summaries of water withdrawals and discharges upstream from any user-selected point on a stream. This new functionality was made possible by creating a Web service that accepts a drainage-basin delineation from StreamStats, overlays it on a spatial layer of water withdrawal and discharge points, extracts the water-use data for the identified points, and sends it back to StreamStats, where it is summarized for the user. The underlying water-use data were extracted from the U.S. Geological Survey's Site-Specific Water-Use Database System (SWUDS) and placed into a Microsoft Access database that was created for this study for easy linkage to the Web service and StreamStats. This linkage of StreamStats with water-use information from SWUDS should enable Maryland regulators and planners to make more informed decisions on the use of water resources in the BRAC area, and the technology should be transferrable to other geographic areas.

\section{Introduction}

On May 13, 2005, the U.S. Department of Defense (DoD) issued a list of suggested military base realignments and closures that would aid in military transformation and reduce costs. Subsequently, the U.S. Congress appointed a Base Realignment and Closure (BRAC) Commission to provide an independent, non-partisan review of DoD's recommendations and ensure the integrity of the BRAC process. The goals of the BRAC recommendations were to support force transformation, address new threats and strategies, consolidate business functions, and provide significant cost savings. The Commission released its final report to the President of the United States on September 8, 2005. The President approved the recommendations on September 15, 2005, and forwarded them to Congress. The recommendations became law on November 9, 2005. The military realignments as a result of the BRAC process are expected to have a substantial impact on the State of Maryland, where the Aberdeen Proving Ground (APG) in Harford County, and Fort George G. Meade (Fort Meade) in Anne Arundel County are expected to grow larger in order to accommodate transferred Army personnel and consolidated operations.

The Maryland Department of Planning (2006) estimates that approximately 25,000 new households will be established in Maryland as a result of BRAC. Of these, approximately 56 percent of them will be established due to new jobs at APG in Harford County, and approximately 42 percent of them will be established due to new jobs at Fort Meade in Anne Arundel County. The remaining 2 percent of new households will be established as a result of new jobs at Joint Base Andrews Naval Air Facility in Prince George's County. This influx of new residents will lead to greater demands for housing, schools, and infrastructure for water, wastewater, power, telecommunications, and transportation, particularly in Harford and Cecil Counties.

The increased demand for water and wastewater capacity resulting from the influx of new residents to BRAC-affected areas will likely lead to applications for new permits for 
water withdrawals and wastewater-discharge permits. The Water Management Administration (WMA) of the Maryland Department of the Environment (MDE) is responsible for evaluating permit applications and issuing these permits (Maryland Department of the Environment, 2009). Making good permitting decisions will require the WMA to understand the natural availability of the affected water resources in relation to current and requested water withdrawals and return flows.

The U.S. Geological Survey (USGS), in cooperation with MDE, began a program of study in January 2008 of the potential impacts of BRAC on water resources in Maryland. The program consisted of four coordinated investigations: water-use activities, modeling of groundwater flow, low-flow statistical analysis for streams, and hydrologic monitoring. This report summarizes the investigation to estimate low-flow statistics for streams that potentially could be affected by new water withdrawals.

Areas in Maryland that will be affected by BRAC are in the Coastal Plain and Piedmont Physiographic Provinces, which are separated by the Fall Line (fig. 1). Fort Meade is in the Coastal Plain Physiographic Province near the Fall Line. Most of the anticipated water-resource impacts from expansion of this facility are expected to occur within the recharge areas of several important aquifers in the Coastal Plain Physiographic Province, although some impacts are also likely to occur in Piedmont Physiographic Province areas adjacent to the base. APG is located within the Coastal Plain Physiographic Province, but most of the increased water use from BRAC-related development is expected to occur in the surrounding counties, which are situated largely within the Piedmont Physiographic Province.

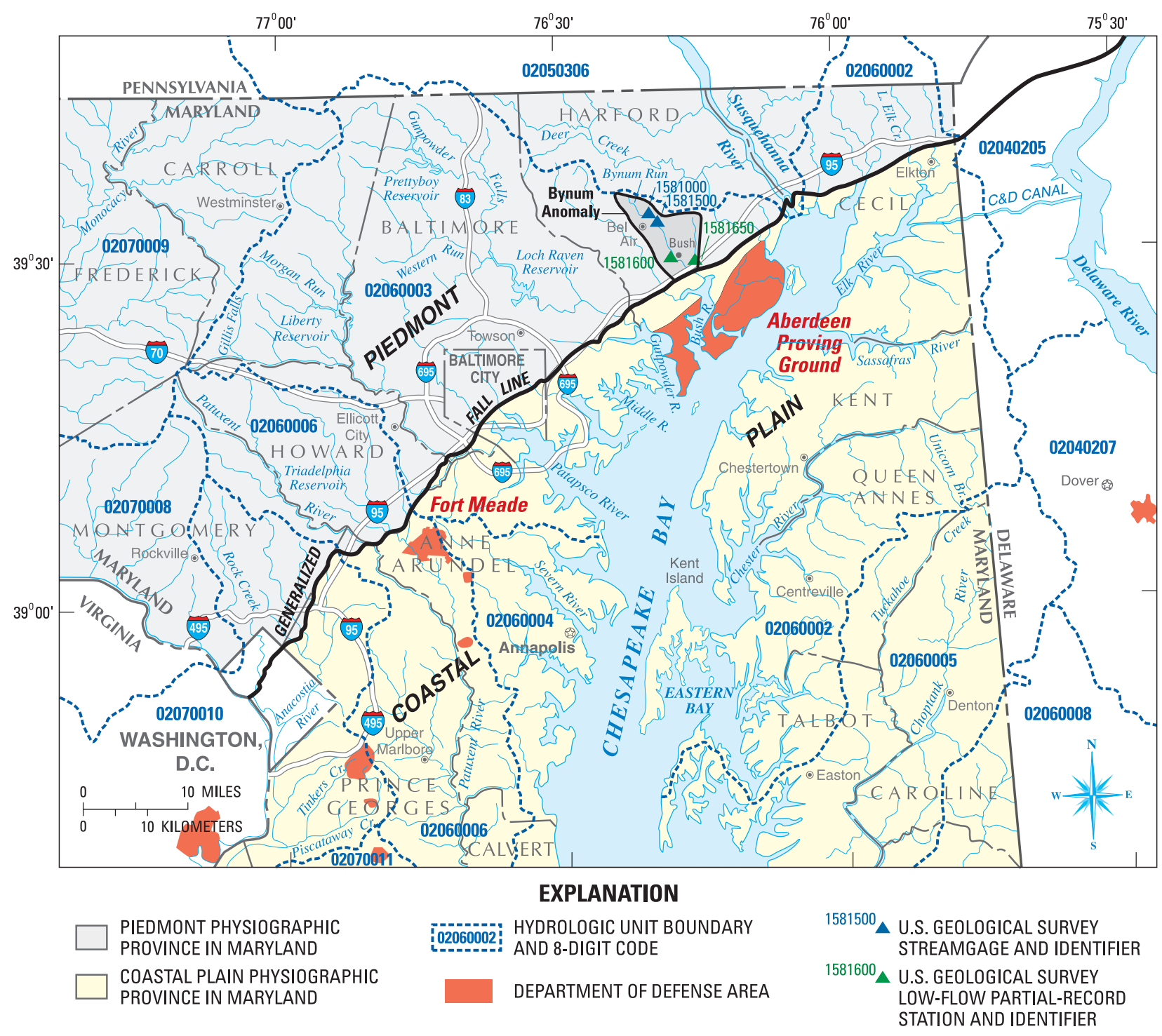

Figure 1. Location of areas affected by Base Realignment and Closure (BRAC) activities in Maryland, including Aberdeen Proving Ground and Fort Meade. 
The investigation to estimate low-flow statistics for streams that potentially could be affected by new water withdrawals as a result of the BRAC process was separated into two major tasks. One task was to modify an existing Web-based decision-support system named StreamStats to aid the WMA in evaluating permit applications for new water withdrawals and pollutant discharges in the BRAC area. The other task was to obtain streamflow measurements at a group of low-flow partial-record (LFPR) stations and relate those measurements to concurrent flows at nearby streamgages so that estimates of selected streamflow statistics at the LFPR stations could be determined from these relations. This report summarizes the first task. A separate report is planned that will summarize the second task.

\section{Purpose and Scope}

The purpose of this report is to describe the StreamStats Web application for Maryland and modifications made to the program that provide summaries of water use for user-selected locations along streams in BRAC-affected areas. This report includes brief descriptions of the study area, the StreamStats Web application, the database from which water-use data are extracted for display in StreamStats, and the method used to link StreamStats and the water-use database. In addition, instructions on how to use StreamStats to obtain the wateruse summaries are provided. Instructions for use of other StreamStats functionality are provided through links from the StreamStats home page at http://streamstats.usgs.gov.

\section{Description of Study Area}

The study area extends from northeast to southwest of Baltimore, Maryland (fig. 1), and includes areas in Maryland that are in hydrologic units 02050306 (Lower Susquehanna River Basin), 02060002 (Chester and Sassafras River Basins), 02060003 (Gunpowder and Patapsco River Basins), 02060004 (Severn River Basin), and 02060006 (Patuxent River Basin) (fig. 1). The counties in Maryland that primarily will be affected by BRAC are, from northeast to southwest, Cecil, Harford, Baltimore, Howard, Anne Arundel, Montgomery, and Prince George's. The City of Baltimore is located approximately centrally within the study area, and also is expected to be affected by BRAC. These areas are located in the Piedmont and Coastal Plain Physiographic Provinces (Fenneman, 1938). The Fall Line, which roughly parallels U.S. Interstate 95 in the study area, separates the two physiographic provinces. The Piedmont Physiographic Province, northwest of the Fall Line, has a gently rolling landscape and streams with relatively high gradients, which drain to the Chesapeake Bay (Carpenter and Hayes, 1996). The Coastal Plain Physiographic Province, southeast of the Fall Line, is an area of low relief adjacent to the Chesapeake Bay. Streams in the Coastal Plain Physiographic Province have relatively flat gradients, and often are affected by tides for substantial distances above their mouths. The Fall Line extends north and south along much of the Eastern United States, and is named as such because numerous waterfalls occur along the line, where rivers transition from the higher Piedmont Physiographic Province onto the lower Coastal Plain Physiographic Province.

APG has been the Army's primary chemical-warfare research and development center since World War I (Spencer and others, 2001). It is in Harford County, primarily on land along the northwestern shore of Chesapeake Bay. BRACrelated development in Harford County is expected to occur primarily in an inverted " $T$ " shape, running northeast to southwest along the Interstate 95 corridor, with a perpendicular axis to the northwest along Maryland Route 24 into Bel Air, although some development also is expected in more sparsely developed areas in Harford and Cecil Counties (Michelle Dobson, Harford County, oral commun., July 2008). From a water-supply perspective, Harford County is concerned that thousands of additional people could be tapping into the fractured-rock aquifers of the Piedmont in areas west and north of Bel Air. Production of water from the fractured rocks already is marginal in some locations (Bolton and others, 2009), and the impact of many additional wells could cause significant declines in areas where municipal water supplies are not yet available.

Fort Meade is an Army installation in Anne Arundel County, Maryland, that primarily supports intelligence, knowledge capital, information management organizations, and installation operations for facilities and infrastructure in support of DoD activities (Anne Arundel County, 2010). The campus of the U.S. National Security Agency (NSA) is near the western boundary of Fort Meade. BRAC will likely add about 5,695 direct new jobs at Fort Meade, while other components of growth expected at Fort Meade, including at the NSA, will likely bring the total of new jobs to about 22,000 (Anne Arundel County, 2010). Development around the facility is expected to expand in almost a radial fashion, depending on accessibility to roads and highways (Anne Arundel County, 2010). Significant amounts of development also are anticipated to take place on the grounds of the fort itself. Numerous row houses have already been constructed on the site of the former base golf course, and more are planned. From a water-resource perspective, Maryland State agencies are concerned that the Fort Meade water-supply system, which relies primarily on groundwater withdrawn from the Patuxent and Patapsco aquifers, could further stress these aquifers. The Patuxent aquifer is used for municipal supply in areas just to the north and east of Fort Meade, and in 2005, at the start of BRAC, it showed a potentiometric surface drawdown equivalent to more than $40 \mathrm{ft}$ (feet) in areas north of the fort (Soeder and others, 2007). Withdrawals of groundwater from the Lower Patapsco aquifer, above the Patuxent aquifer, also are a concern. Fort Meade is within the recharge area of the Lower Patapsco aquifer, and pumpage, if excessive, could interfere with aquifer recharge. 


\section{StreamStats Implementation for Maryland}

StreamStats is a Web-based Geographic Information System (GIS) application (fig. 2) that provides users with access to an assortment of analytical tools that are useful for water-resources planning and management, engineering design, and other applications. StreamStats was developed by the USGS, in cooperation with Environmental Systems Research Institute, Inc. (ESRI), using the ArcHydro Data Model and Tools (Environmental Systems Research Institute, Inc., 2010a) as its foundation. StreamStats functionality can be accessed through a map-based user interface that appears in the user's Web browser (fig. 2), or individual functions can be requested remotely as Web services by other Web or desktop computer applications.
The primary functionality of StreamStats is to enable users to (1) determine the drainage-basin boundary for a selected site on a stream; (2) compute the drainage area and other physical and climatic characteristics of the drainage basin; and (3) estimate various streamflow statistics for the selected site, assuming natural flow conditions at the site. In addition to this functionality, StreamStats can provide published streamflow statistics and other information for USGS streamgages, and it has numerous other tools that are described in a Fact Sheet by Ries and others (2008), and in the StreamStats user instructions. The StreamStats home page (http://streamstats.usgs.gov) provides a more detailed description of the application, links to the Maryland application and those for other states, as well as links to the user instructions and other documentation. For this study, StreamStats was modified to provide summaries of water use for user-selected sites. This functionality is further described on the following pages.

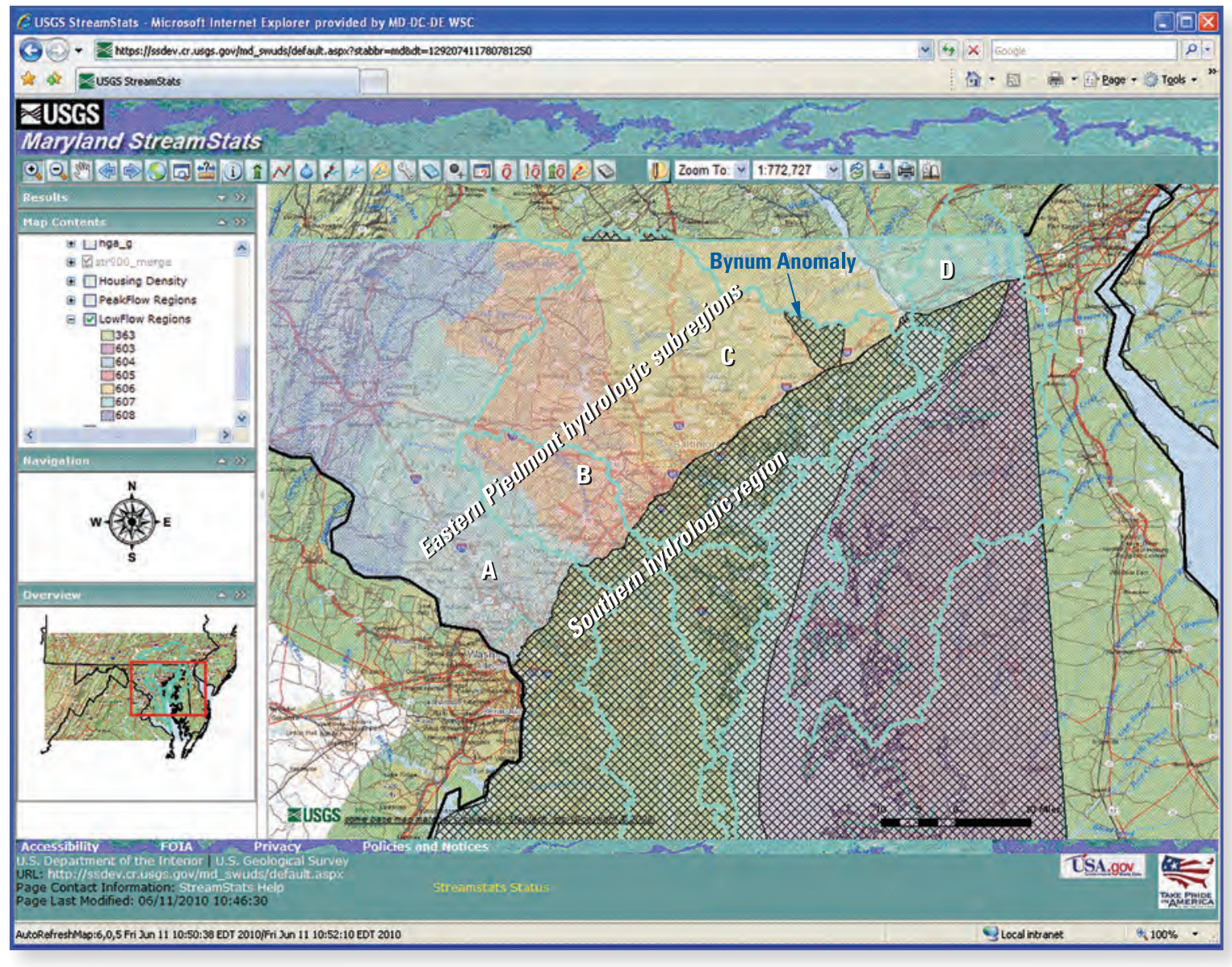

Figure 2. View of the StreamStats user interface for Maryland with aqua lines showing the hydrologic accounting units in which the application is implemented and colored areas corresponding to the low-flow hydrologic regions of Carpenter and Hayes (1996). (Hatched areas indicate where regression equations are not available for estimating low-flow statistics.) 
Table 1. Peak-flow regression equations for the Piedmont and Western Coastal Plain in Maryland.

$\left[Q_{x}\right.$ is the instantaneous peak flow that occurs, on average, once in $x$ years, in cubic feet per second; $A$ is drainage area, in square miles; $F$ is percentage of forested land; ranges of applicability apply to all equations within a region. Equations are from Dillow (1996).]

\begin{tabular}{|c|c|c|c|c|c|c|c|}
\hline \multirow{2}{*}{$\begin{array}{c}\text { Peak-flow } \\
\text { recurrence } \\
\text { interval } \\
\text { (years) }\end{array}$} & \multirow[b]{2}{*}{ Equation } & \multirow{2}{*}{$\begin{array}{c}\text { Standard } \\
\text { error of } \\
\text { estimate } \\
\text { (percent) }\end{array}$} & \multirow{2}{*}{ 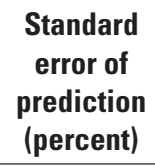 } & \multirow{2}{*}{$\begin{array}{l}\text { Equivalent } \\
\text { years of } \\
\text { record }\end{array}$} & \multicolumn{3}{|c|}{ Ranges of applicability } \\
\hline & & & & & Variable & Minimum & Maximum \\
\hline \multicolumn{8}{|c|}{ Piedmont region } \\
\hline 2 & $\mathrm{Q}_{2}=451 \mathrm{~A}^{0.635}(\mathrm{~F}+10)^{-0.266}$ & 38 & 39 & 3 & A & 0.26 & 165 \\
\hline 5 & $\mathrm{Q}_{5}=839 \mathrm{~A}^{0.6065}(\mathrm{~F}+10)^{-0.248}$ & 34 & 36 & 7 & $\mathrm{~F}$ & 0 & 96 \\
\hline 10 & $\mathrm{Q}_{10}=1,210 \mathrm{~A}^{0.589}(\mathrm{~F}+10)^{-0.242}$ & 33 & 35 & 10 & & & \\
\hline 25 & $\mathrm{Q}_{25}=1,820 \mathrm{~A}^{0.574}(\mathrm{~F}+10)^{-0.239}$ & 34 & 37 & 15 & & & \\
\hline 50 & $\mathrm{Q}_{50}=2,390 \mathrm{~A}^{0.565}(\mathrm{~F}+10)^{-0.240}$ & 36 & 40 & 17 & & & \\
\hline 100 & $\mathrm{Q}_{100}=3,060 \mathrm{~A}^{0.557}(\mathrm{~F}+10)^{-0.241}$ & 39 & 43 & 19 & & & \\
\hline 500 & $\mathrm{Q}_{500}=5,190 \mathrm{~A}^{0.543}(\mathrm{~F}+10)^{-0.245}$ & 48 & 52 & 20 & & & \\
\hline \multicolumn{8}{|c|}{ Western Coastal Plain region } \\
\hline 2 & $\mathrm{Q}_{2}=1,410 \mathrm{~A}^{0.761}(\mathrm{~F}+10)^{-0.782}$ & 50 & 55 & 2 & A & 0.3 & 55 \\
\hline 5 & $\mathrm{Q}_{5}=1,780 \mathrm{~A}^{0.769}(\mathrm{~F}+10)^{-0.687}$ & 46 & 51 & 4 & F & 19 & 83 \\
\hline 10 & $\mathrm{Q}_{10}=1,910 \mathrm{~A}^{0.771}(\mathrm{~F}+10)^{-0.613}$ & 45 & 51 & 7 & & & \\
\hline 25 & $\mathrm{Q}_{25}=2,000 \mathrm{~A}^{0.772}(\mathrm{~F}+10)^{-0.519}$ & 46 & 54 & 10 & & & \\
\hline 50 & $\mathrm{Q}_{50}=2,060 \mathrm{~A}^{0.771}(\mathrm{~F}+10)^{-0.452}$ & 49 & 58 & 12 & & & \\
\hline 100 & $\mathrm{Q}_{100}=2,140 \mathrm{~A}^{0.770}(\mathrm{~F}+10)^{-0.391}$ & 52 & 63 & 13 & & & \\
\hline 500 & $\mathrm{Q}_{500}=2,380 \mathrm{~A}^{0.765}(\mathrm{~F}+10)^{-0.263}$ & 64 & 77 & 14 & & & \\
\hline
\end{tabular}

The StreamStats application for Maryland was first implemented in 2007, and worked only in the Gunpowder and Patapsco River Basins. Coverage now extends to Maryland areas of the five 8-digit Hydrologic Unit Code accounting units (HUCs) in the BRAC study area, including the ChesterSassafras (02060002), the Lower Susquehanna (02050306), the Gunpowder-Patapsco (02060003), the Severn (02060004), and the Patuxent (02060006) HUCs (Seaber and others, 1987) (figs. 1 and 2). Additional information about HUCs is available online at $h t t p: / / w a t e r . u s g s . g o v / G I S / h u c . h t m l$.

StreamStats provides two tools for estimating streamflow statistics for ungaged sites. One tool provides the estimates by solving regression equations. The other tool transfers the flow per unit area for a nearby streamgage on the same stream to the location of the ungaged site. Regression equations are developed by statistically relating the streamflow statistics to the basin characteristics for a group of data-collection stations within a region. Estimates of streamflow statistics for ungaged sites can then be obtained by measuring the basin characteristics for the ungaged site and inserting them into the regression equations. StreamStats automates this process.

StreamStats for Maryland can compute estimates of peak streamflows for ungaged sites at the 2-, 5-, 10-, 25-, 50-, 100-, and 500-year recurrence intervals (peak streamflows having a $50,20,10,2,1$, and 0.2 percent probability of occurring in any given year, respectively) using regression equations developed by Dillow (1996). The application also is able to compute 7-, 14-, and 30-day mean low flows that occur, on average, once in 2,10 , and 20 years using regression equations developed by Carpenter and Hayes (1996).

Dillow (1996) divided Maryland into five hydrologic regions, based primarily on physiography, and developed separate peak-flow equations for each hydrologic region. The regression equations for the Western Coastal Plain and the Piedmont hydrologic regions were implemented in StreamStats for the BRAC study. The Western Coastal Plain hydrologic region is the part of the Coastal Plain Physiographic Province that is bounded on the northwest by the Fall Line and on the east by the western shore of the Chesapeake Bay. The Piedmont hydrologic region corresponds with the Piedmont Physiographic Province. The equations are listed in table 1 . The basin characteristics used as explanatory variables in both sets of regional equations included drainage area and percentage of forest cover. These characteristics were determined manually rather than by use of a GIS. Dillow (1996) suggested determining drainage area for ungaged 
sites by drawing the basin boundary on a topographic map and using a planimeter to determine the area. Dillow also suggested using a planimeter to determine the total area of forest within the basin, as indicated by green-shaded areas on 1:24,000-scale USGS topographic maps, dividing the forested area by the drainage area, and then multiplying by 100 to obtain the percentage of forested area for ungaged sites.

Using the method suggested by Dillow (1996) to determine the percentage of forest cover would have required the development of a seamless digital dataset of forested areas by extracting the green areas from scanned images for each 1:24,000-scale USGS topographic map for the study area, which was beyond the scope of this study. Instead, the National Land Cover Database of 2001 (NLCD-http://www. $\left.m r l c . g o v / m r l c 2 k \_n l c d . a s p\right)$ was used to compute percentages of forested land area for StreamStats.

Comparisons were made between the percentages of forest cover computed by StreamStats and the published values for 25 stations that were used by Dillow (1996) to develop the peak-flow regression equations. Of the stations, 21 were in the Piedmont hydrologic region and 4 were in the Western Coastal Plain hydrologic region. The comparisons of values of percentage of forest cover for the Piedmont yielded an average difference between the published values and the values computed by StreamStats of +0.8 percent, with differences for individual stations ranging from -42.7 to +72.6 percent. The small average difference in the values indicates that, on average, there is little bias in the StreamStats values for the Piedmont hydrologic region. The differences in values may be attributable to the differences in the source material and methods used to obtain the values, but they also may be due to actual changes in land use during the interval between development of the USGS topographic maps and development of the NLCD.

The peak-flow regression equations for the Piedmont hydrologic region are not highly sensitive to the entered values of the percentage of forested land area. Although the differences in the values for individual stations were large, estimates of the 100-year flood flows determined from the equations were consistently within 10 percent of the published values. As a result, the peak-flow regression equations were implemented in StreamStats for the Piedmont hydrologic region, but actual standard errors of prediction for the estimates are likely larger than those provided in table 1 and in the StreamStats output.

The comparisons of values of percentage of forest cover for the four streamgages in the Western Coastal Plain hydrologic region yielded an average difference of -55.8 percent, with differences for individual stations ranging from -29.2 to -80.0 percent. The peak-flow regression equations for the Western Coastal Plain hydrologic region were much more sensitive to the entered values of the percentage of forested land area than the equations for the Piedmont hydrologic region, and the average difference of -55.8 percent indicates substantial bias in the measurements for this region. As a result, the peak-flow regression equations were not implemented in StreamStats for the Western Coastal Plain hydrologic region.

Like Dillow (1996), Carpenter and Hayes (1996) divided Maryland into hydrologic regions, based primarily on physiography, and developed separate low-flow equations for each hydrologic region. Carpenter and Hayes (1996) developed regression equations for four separate subregions within the Piedmont Physiographic Province, which they named Eastern Piedmont Subregions A through D. The equations are listed in table 2. Drainage area was the only explanatory variable used in these regression equations. Carpenter and Hayes (1996) were not able to determine regression equations for a small area within Eastern Piedmont Subregion C, which they named the Bynum Anomaly. The section titled "Estimating Streamflow Statistics for Ungaged Sites in the Bynum Anomaly" explains how estimates of streamflow statistics can be obtained for this area.

Carpenter and Hayes (1996) also were not able to define regression equations for an area that they designated as the Southern hydrologic region, which is roughly equivalent in spatial extent to the Western Coastal Plain of Dillow (1996). They determined that the density of streamgages in the southern region was insufficient to develop regression equations for the region. As an alternative, they suggested estimating lowflow statistics for ungaged sites in this region on the basis of a distance-weighted average of the flows per unit area for the low-flow statistics for streamgages in the region. Distances are measured from the centroid of the basin for the ungaged site to the centroids of the basins for the streamgages. An automated procedure is not available in StreamStats for determining the low-flow estimates based on the method that Carpenter and Hayes (1996) suggested for the Southern hydrologic region.

The hydrologic regions that apply to the regression equations from both the Dillow (1996) and Carpenter and Hayes (1996) reports can be displayed as separate layers on the map in the Maryland StreamStats application. Boundaries used in StreamStats for the low-flow regions do not correspond exactly with the boundaries defined on plate 1 of Carpenter and Hayes (1996). The original boundaries were drawn by hand on a small-scale State map. When these boundaries were digitized and overlain in a GIS on a map of the 8-digit HUCs and streams in the study area, it was noted that the boundaries from their report often came close to but crossed back and forth across the HUC boundaries in some cases and the major streams in other cases. As a result, when StreamStats was first implemented using the boundaries from Carpenter and Hayes (1996), drainage areas determined from StreamStats often had very large percentages of their areas in one region and very small percentages in another region, where the entire drainage area probably should have been within one region. As a result, the low-flow hydrologic-region boundaries were edited to agree exactly with HUC boundaries and with major streams in areas where it was concluded that was the original intent of Carpenter and Hayes (1996). 
Table 2. Low-flow regression equations for subregions $A$ through $D$ in the Eastern Piedmont in Maryland.

[xQy is annual minimum $\mathrm{x}$-day mean flow that occurs, on average, once in y years, in cubic feet per second; $\mathrm{A}$ is drainage area, in square miles; ranges of applicability apply to all equations within a region. Equations are from Carpenter and Hayes (1996).]

\begin{tabular}{|c|c|c|c|c|c|}
\hline \multirow{2}{*}{$\begin{array}{l}\text { Peak-flow } \\
\text { recurrence } \\
\text { interval }\end{array}$} & \multirow{2}{*}{ Equation } & \multirow{2}{*}{$\begin{array}{l}\text { Standard error of } \\
\text { prediction } \\
\text { (percent) }\end{array}$} & \multicolumn{3}{|c|}{ Ranges of applicability } \\
\hline & & & Variable & Minimum & Maximum \\
\hline \multicolumn{6}{|c|}{ Subregion A } \\
\hline $7 \mathrm{Q} 2$ & $7 \mathrm{Q} 2=0.201 \mathrm{~A}^{1.000}$ & 16 & A & 2.45 & 101 \\
\hline $7 \mathrm{Q} 10$ & $7 \mathrm{Q} 10=0.0579 \mathrm{~A}^{1.076}$ & 31 & & & \\
\hline $7 \mathrm{Q} 20$ & $7 \mathrm{Q} 20=0.0357 \mathrm{~A}^{1.103}$ & 44 & & & \\
\hline $14 \mathrm{Q} 2$ & $14 \mathrm{Q} 2=0.235 \mathrm{~A}^{0.983}$ & 16 & & & \\
\hline 14Q10 & $14 \mathrm{Q} 10=0.0684 \mathrm{~A}^{1.057}$ & 30 & & & \\
\hline 14Q20 & $14 \mathrm{Q} 20=0.0446 \mathrm{~A}^{1.077}$ & 42 & & & \\
\hline 30Q2 & $30 \mathrm{Q} 2=0.273 \mathrm{~A}^{0.991}$ & 17 & & & \\
\hline $30 \mathrm{Q} 10$ & $30 \mathrm{Q} 10=0.0885 \mathrm{~A}^{1.051}$ & 24 & & & \\
\hline 30Q20 & $30 \mathrm{Q} 20=0.0655 \mathrm{~A}^{1.056}$ & 33 & & & \\
\hline \multicolumn{6}{|c|}{ Subregion B } \\
\hline $7 \mathrm{Q} 2$ & $7 \mathrm{Q} 2=0.329 \mathrm{~A}^{0.955}$ & 26 & A & 2.01 & 165 \\
\hline $7 \mathrm{Q} 10$ & $7 \mathrm{Q} 10=0.136 \mathrm{~A}^{0.956}$ & 44 & & & \\
\hline $7 \mathrm{Q} 20$ & $7 \mathrm{Q} 20=0.0966 \mathrm{~A}^{0.962}$ & 55 & & & \\
\hline 14Q2 & $14 \mathrm{Q} 2=0.337 \mathrm{~A}^{0.962}$ & 24 & & & \\
\hline 14Q10 & $14 \mathrm{Q} 10=0.149 \mathrm{~A}^{0.964}$ & 41 & & & \\
\hline 14Q20 & $14 \mathrm{Q} 20=0.113 \mathrm{~A}^{0.962}$ & 48 & & & \\
\hline 30Q2 & $30 \mathrm{Q} 2=0.353 \mathrm{~A}^{0.973}$ & 22 & & & \\
\hline $30 \mathrm{Q} 10$ & $30 \mathrm{Q} 10=0.178 \mathrm{~A}^{0.964}$ & 38 & & & \\
\hline 30Q20 & $30 \mathrm{Q} 20=0.145 \mathrm{~A}^{0.955}$ & 43 & & & \\
\hline \multicolumn{6}{|c|}{ Subregion C, except Bynum Anomaly } \\
\hline $7 \mathrm{Q} 2$ & $7 \mathrm{Q} 2=0.371 \mathrm{~A}^{1.048}$ & 12 & A & 2.09 & 133 \\
\hline $7 \mathrm{Q} 10$ & $7 \mathrm{Q} 10=0.164 \mathrm{~A}^{1.092}$ & 20 & & & \\
\hline $7 \mathrm{Q} 20$ & $7 \mathrm{Q} 20=0.117 \mathrm{~A}^{1.128}$ & 25 & & & \\
\hline 14Q2 & $14 \mathrm{Q} 2=0.405 \mathrm{~A}^{1.037}$ & 10 & & & \\
\hline 14Q10 & $14 \mathrm{Q} 10=0.190 \mathrm{~A}^{1.069}$ & 19 & & & \\
\hline 14Q20 & $14 \mathrm{Q} 20=0.142 \mathrm{~A}^{1.092}$ & 24 & & & \\
\hline 30Q2 & $30 \mathrm{Q} 2=0.441 \mathrm{~A}^{1.031}$ & 8.9 & & & \\
\hline 30Q10 & $30 \mathrm{Q} 10=0.220 \mathrm{~A}^{1.060}$ & 18 & & & \\
\hline 30Q20 & $30 \mathrm{Q} 20=0.170 \mathrm{~A}^{1.081}$ & 12 & & & \\
\hline \multicolumn{6}{|c|}{ Subregion D } \\
\hline 7Q2 & $7 \mathrm{Q} 2=0.186 \mathrm{~A}^{1.160}$ & 17 & $\mathrm{~A}$ & 3.05 & 287 \\
\hline $7 \mathrm{Q} 10$ & $7 \mathrm{Q} 10=0.0720 \mathrm{~A}^{1.233}$ & 20 & & & \\
\hline $7 \mathrm{Q} 20$ & $7 \mathrm{Q} 20=0.0526 \mathrm{~A}^{1.143}$ & 23 & & & \\
\hline 14Q2 & $14 \mathrm{Q} 20=0.216 \mathrm{~A}^{1.143}$ & 18 & & & \\
\hline 14Q10 & $14 \mathrm{Q} 10=0.0836 \mathrm{~A}^{1.215}$ & 19 & & & \\
\hline 14Q20 & $14 \mathrm{Q} 20=0.0597 \mathrm{~A}^{1.243}$ & 22 & & & \\
\hline 30Q2 & $30 \mathrm{Q} 2=0.282 \mathrm{~A}^{1.106}$ & 23 & & & \\
\hline 30Q10 & $30 \mathrm{Q} 10=0.109 \mathrm{~A}^{1.180}$ & 21 & & & \\
\hline 30Q20 & $30 \mathrm{Q} 20=0.0807 \mathrm{~A}^{1.202}$ & 22 & & & \\
\hline
\end{tabular}




\section{Site-Specific Water-Use Data System (SWUDS) and Available Water-Use Data}

The USGS has developed the national Site-Specific Water-Use Data System (SWUDS) to store site- and ownerspecific water-use information, site-based measurements, and estimates of water-use values associated with a site or owner. SWUDS is a part of the internal National Water Information System (NWIS) used by the USGS to store, process, and serve all types of water data. The database runs within the Ingres database management system on a computer with a Unix operating system. SWUDS supports a link-node data structure where sites of water withdrawals, returns, and uses are represented as nodes and conveyances are represented as the links between the sites. This structure allows for tracking the movement of water from site to site (nodes) through the conveyances (links) (fig. 3). The conveyance capacity and conveyance type (pipe, canal, ditch, or stream) can be stored along with the type of water conveyed (groundwater, surface water, or treated water). All water-quantity data (annual or monthly) are associated with a conveyance.

Prior to this study, only water-withdrawal data were stored in SWUDS for Maryland. These data were stored as total withdrawals by permit. Water withdrawals by specific well or intake, conveyance, and discharge were needed for a better understanding of how upstream water-use activities can affect streamflow at specific locations. As a result, data from State, private, and Federal databases (fig. 4) were compiled, analyzed, and related to allow for better tracking of water. Data from four State programs were integrated and added to SWUDS for this study. The Maryland programs and associated databases include:

1. Water-allocation permitting and reporting program data from the Regulatory Analysis Management System (RAMS) water-use database;

2. Well-construction permitting program data from the Well Construction Permit database;

3. Drinking-water program data from the Public Drinking Water Information System (PDWIS) database; and

4. Wastewater program data from the National Pollutant Discharge Elimination System (NPDES) database of the U.S. Environmental Protection Agency.

Other non-state databases included business information from Dun \& Bradstreet, Inc. and data in an older version of SWUDS for Maryland. These data were compiled into an updated version of SWUDS for Maryland.

Data describing major users who withdraw groundwater or surface water or have return flow to surface water were integrated from all six data sources, analyzed for completeness and accuracy, and entered into SWUDS. The database includes information and time series for all active permitted groundwater and surface-water withdrawals of greater than $10,000 \mathrm{gal} / \mathrm{d}$ (gallons per day). Wells in the Well Construction Permit database were matched to the Water Appropriation Permit database by their Water Appropriation Identification Number (WAPID), which appears in both databases. RAMS provided aquifer information and the general locations for surface-water intakes and identified the resources from which the water was withdrawn. The Well Construction Permit database provided precise location information for the aquifers. The PDWIS database provided precise location information for all surface water withdrawn for drinking water. Community water systems (CWSs) in RAMS were matched based on Water Appropriation Permit information, usually by owner name, with the PDWIS database information to extract the higher credibility location information for active wells from the PDWIS database.

\section{Development of a Linkage Between StreamStats and the Site-Specific Water-Use Data System (SWUDS)}

After data compilation into SWUDS was complete, data for 2005 on the quantity of water withdrawn from wells or surface-water intakes and returned through discharge pipes to surface water, as well as ancillary data, were retrieved from SWUDS and placed into the SWUDS Data Warehouse (SWUDS-DW), a new relational database that was created by the USGS. The SWUDS-DW was built using Microsoft Access so that it shares the same computer operating system as StreamStats, and thus facilitates the linking of the water-use data with StreamStats. In addition, the SWUDS-DW provides a more user-friendly environment for working with the wateruse data than SWUDS. A Visual Basic for Applications (VBA) program was developed to transfer data from SWUDS to the SWUDS-DW, which maintains a link-node topology and thus is consistent with the original SWUDS concept of water conveyances. SWUDS data were moved to the SWUDS-DW in two basic tables; attributed sites, and their associated wateruse values. Site coordinates maintained in SWUDS were plotted to points using the ArcGIS software (Environmental Research Systems, Inc., 2010b) and assigned a unique identifier equal to the unique site_id field in the attributed sites table of the SWUDS-DW. Water-use-quantity values were reported monthly, in million gallons per day (Mgal/d). The monthly values were stored in the water-use values table of the SWUDS-DW. The two tables were linked by means of a common site_id field.

Data from the SWUDS-DW were imported into an ArcHydro geo-database using the ArcMap GIS software (Environmental Research Systems, Inc., 2010b) and the ArcHydro Data Model and Tools (Maidment, 2002). Wateruse points were added using ArcCatalog tools and segregated into WaterWithdrawal and WaterDischarge types based on 


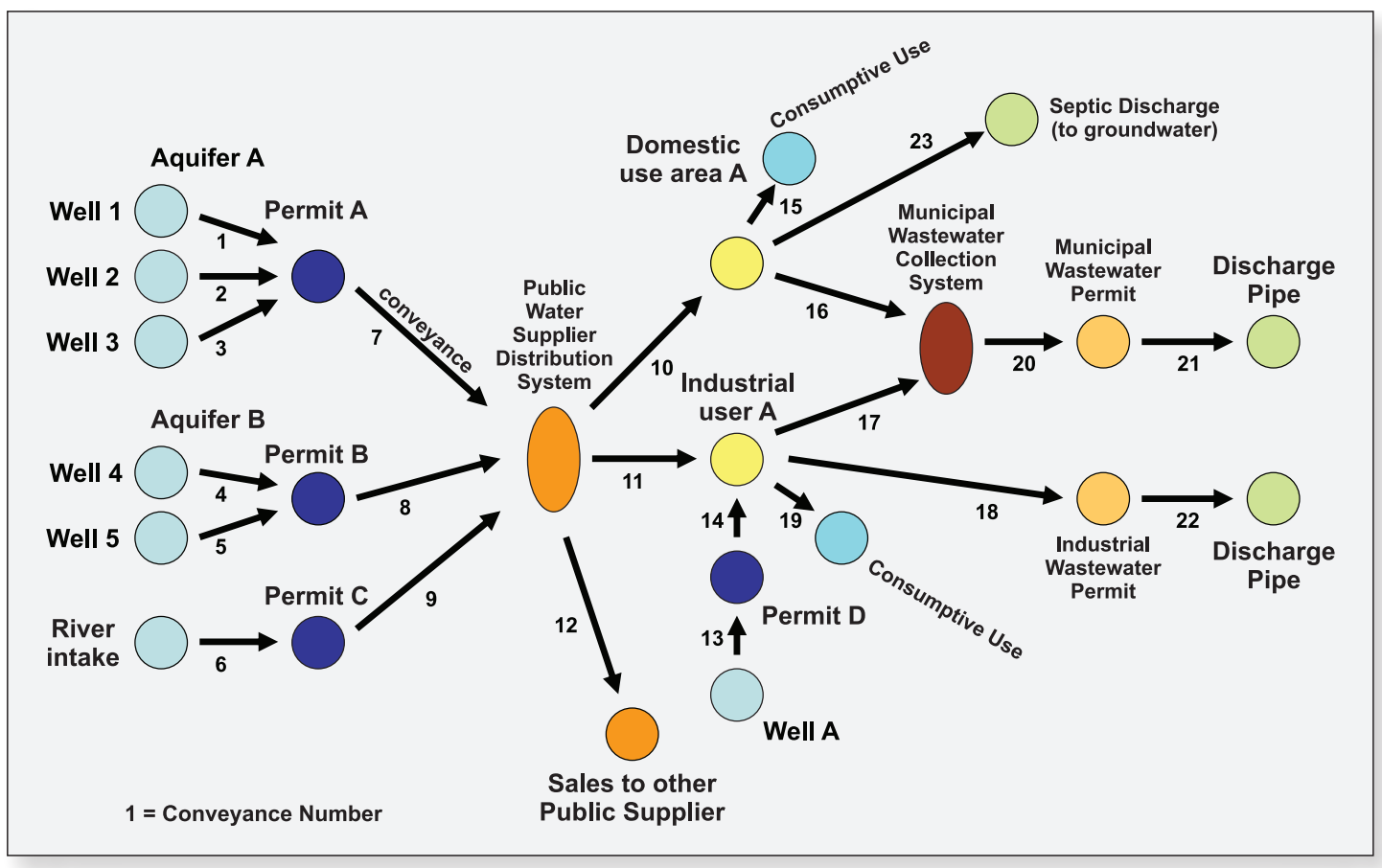

Figure 3. An example of modeling conveyance-based water-use data in the Site-Specific Water-Use Data System (SWUDS) showing 22 sites and 23 numbered conveyances.

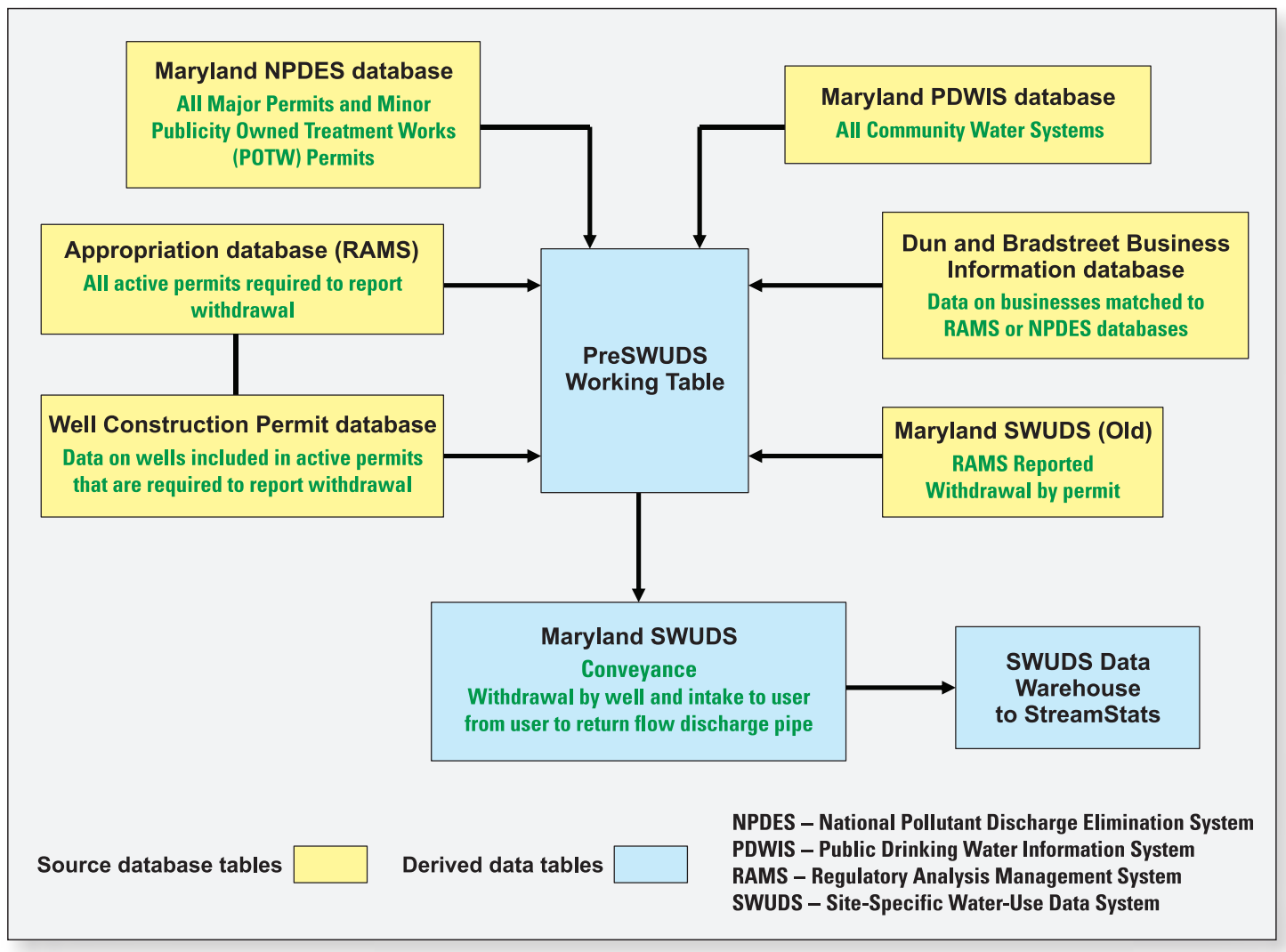

Figure 4. Data and databases used in construction of the Maryland Site-Specific Water-Use Data System (SWUDS) conveyance database. 
their SWUDS site-type codes. Water-withdrawal and waterdischarge data relationship classes were defined in ArcCatalog. These relationship classes were one to many (one site with potentially many withdrawal or discharge records) and were related by site_id. Monthly quantity records were loaded into the geo-database as time-series data using available ArcCatalog tools.

A Web service was developed using Visual Basic .NET (Microsoft Corp., 2009) to process the water-use data within the ArcGIS Server software environment. The Web service requires a single polygon representing a watershed as an input argument. This watershed polygon is sent to the Web service by StreamStats through the process described in the "Estimating Streamflow Statistics by Use of Regression Equations and Obtaining Water-Use Summaries for Ungaged Sites" section. The Web service overlays the watershed polygon on the water-use points layer and selects the points that fall within the polygon. The program then captures all of the water-use records related to each water-use point within the watershed. Next, it creates two XML tables, which it delivers back to StreamStats, where they are inserted into an output Web page that is generated when a user requests estimates of streamflow statistics from regression equations for an ungaged site. The first table provides totals of withdrawals and returns for each month and annual averages, as well as net values computed by subtracting total withdrawals from total returns. The second table is viewable only by users who have been given login privileges, and contains a list of all water-use points in the watershed that includes site_ids, owner names, and other information. This process of linking StreamStats with data from SWUDS should be easily transferable for use in other states.

\section{Obtaining Streamflow Statistics and Water-Use Summaries from the Maryland StreamStats Web Application}

The Maryland StreamStats Web application can be accessed from the national StreamStats home page at http:// streamstats.usgs.gov. The home page provides a brief description of the application. A gray box to the left of the page (fig. 5) provides links to other pages that document and provide access to the application. This gray box is duplicated on all other StreamStats Web pages for easy navigation. It is highly recommended that users read the linked documentation before attempting to use the application.

The State Applications link from the home page is used to access the individual state applications. It presents a map of the United States with individual states shown in different colors depending on their implementation status. Users can access the introductory page for Maryland either by selecting

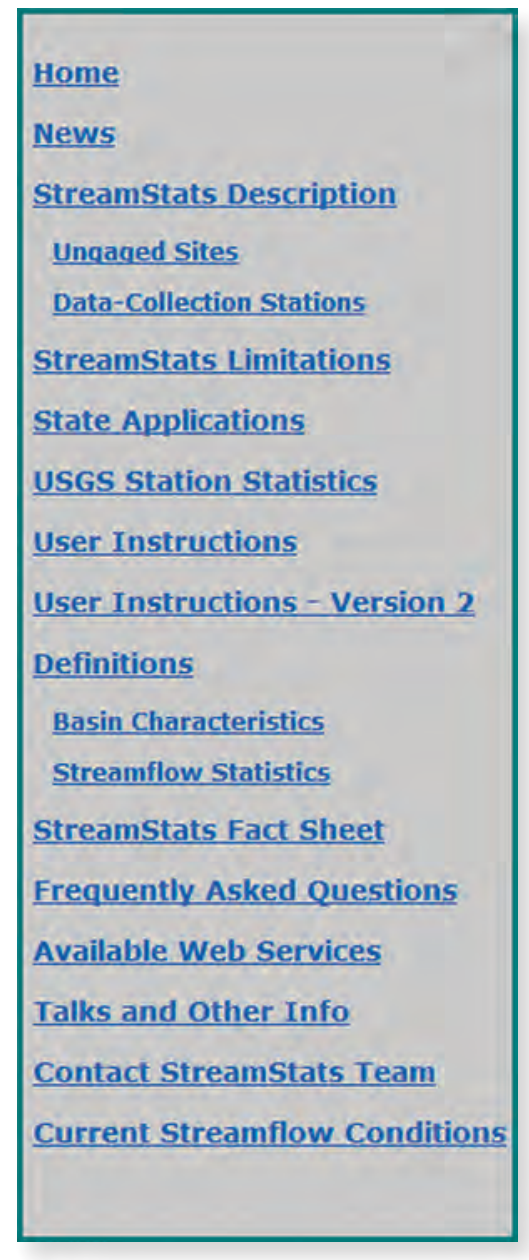

Figure 5. The StreamStats link frame that appears on each Web page. the state name from the scroll list at the top of the page, or by selecting Maryland on the national map.

The Maryland introductory page (1) identifies the areas in Maryland where StreamStats is currently implemented, (2) identifies the streamflow statistics for which there are regression equations available for estimating those statistics for ungaged sites, (3) identifies and provides links to the reports that describe the development of the equations, (4) provides a link to the state application, (5) describes limitations for use of the application, and (6) identifies MDE as the agency that worked in cooperation with the USGS to implement Maryland StreamStats. Users who plan to estimate streamflow statistics for ungaged sites should review the linked reports to understand how the regression equations were developed, and how they should be applied.

The Interactive Map link provides access to the application. For security reasons, some information from StreamStats that is needed by the MDE and other State and Federal agencies cannot be made available to the general public. This information is primarily detailed withdrawal and discharge locations and site-specific withdrawal and discharge rates. When 
the Interactive Map link is selected, a new Web browser window will appear on the user's computer desktop that allows users to enter a login identification number or name (ID) and a password to gain access to the secure information. Users who do not need access to the secure information can click on the Continue button to gain access to the non-secure functionality. Also in this window is a link that allows users to request a login ID and password from MDE, which manages access to the secure information. After either clicking on the Continue button (for regular users) or logging in (for approved users), a new Web page will appear that contains the StreamStats user interface for Maryland.

\section{Maryland StreamStats User Interface}

The Maryland StreamStats user interface (fig. 2) allows users to locate, select, and obtain information for gaged and ungaged sites of interest. The largest part of the interface consists of the Map Frame, which displays default and selected digital map layers. The Console, to the left of the map, allows control of the display of map layers and map navigation, and provides information about the map. The Toolbar above the map frame contains a series of buttons (tools) that are used to change the scale (zooming in and out) and the center (panning) of the map, and allow users to initiate the various StreamStats functions.

This report does not fully describe all of the available functions. The Help button, located at the top right of the Toolbar, gives access to brief directions for use of each of the buttons. Complete documentation can be accessed through the links provided on the main and other StreamStats Web pages.

\section{Obtaining Streamflow Statistics for Data- Collection Stations}

StreamStats provides convenient access to descriptive information, basin characteristics, and streamflow statistics for USGS data-collection stations. Users can zoom in to the location of a data-collection station in the user interface, click on the Gaging Station Information button, and then click on the station symbol to obtain a report that contains available information for the station.

Descriptive information provided in the StreamStats output for the data-collection stations includes: the USGS station identification number, station name, station type, period of record, latitude, longitude, hydrologic unit code, major drainage basin name, county, U.S. Census Bureau Minor Civil Division (MCD) name, directions to locate the station, and remarks indicating any effects of human impacts or other pertinent information about the stations. Only previously published basin characteristics and streamflow statistics are available from StreamStats. The output contains citations to the original source reports that explain the methods used to determine the information. The Definitions links from the StreamStats homepage define the Streamflow Statistics and
Basin Characteristics provided in the output. Water-use summaries can be obtained for data-collection stations by following the instructions for ungaged sites that are provided in the following section and selecting the location of the data-collection station on the map in the StreamStats user interface.

\section{Estimating Streamflow Statistics by Use of Regression Equations and Obtaining Water-Use Summaries for Ungaged Sites}

StreamStats can estimate streamflow statistics for ungaged sites either on the basis of regional regression equations or the known flows for nearby streamgages. Both methods are discussed in the following sections. Water-use summaries are provided only with estimates obtained on the basis of regional regression equations.

To obtain estimates of streamflow statistics from regression equations and a water-use summary for an ungaged site, users of Maryland StreamStats should (1) use the Zoom In button or Zoom To tools to display the location of the site of interest on the map at a scale of at least 1:24:000, (2) click on the Point Delineation tool button and then on the site of interest on the map to obtain the drainage basin for the site (fig. 6), and finally (3) click on the Estimate Flows using Regression Equations tool button to obtain the estimates and the wateruse summary. When the process is completed, a Web browser window will appear that reports, from top to bottom, the date and time of the analysis, the location of the selected ungaged site, the basin characteristics used as explanatory variables in the regression equations, the estimated streamflow statistics and indicators of the errors associated with the estimates, and the water-use summary for the site (fig. 7). Site-specific wateruse information also is provided to users with login access. Currently (2010), withdrawal and return information are available only for 2005. As water-use information is entered into SWUDS for 2006 and beyond, StreamStats will be able to report this additional information.

StreamStats determines the drainage-basin boundary for a selected ungaged site by use of a Digital Elevation Model (DEM), which is a regularly spaced grid of elevation points, and a digital representation of the stream network. The DEM used for Maryland was a 10-meter grid from the National Elevation Dataset (Gesch and others, 2009). The stream network used was from the high-resolution (1:24,000-scale) National Hydrography Dataset (Simley and Carswell, 2009). The DEM used for delineation was processed to assure agreement with the stream network and with previously digitized drainage-basin delineations from the Watershed Boundary Dataset (National Resources Conservation Service, 2009). This processing minimizes errors that can occur when using a DEM for drainage-area delineations. The processed DEM is used only for delineations. Any basin characteristics that rely on elevation information, such as mean basin elevation, are computed from the original, unprocessed DEM. 


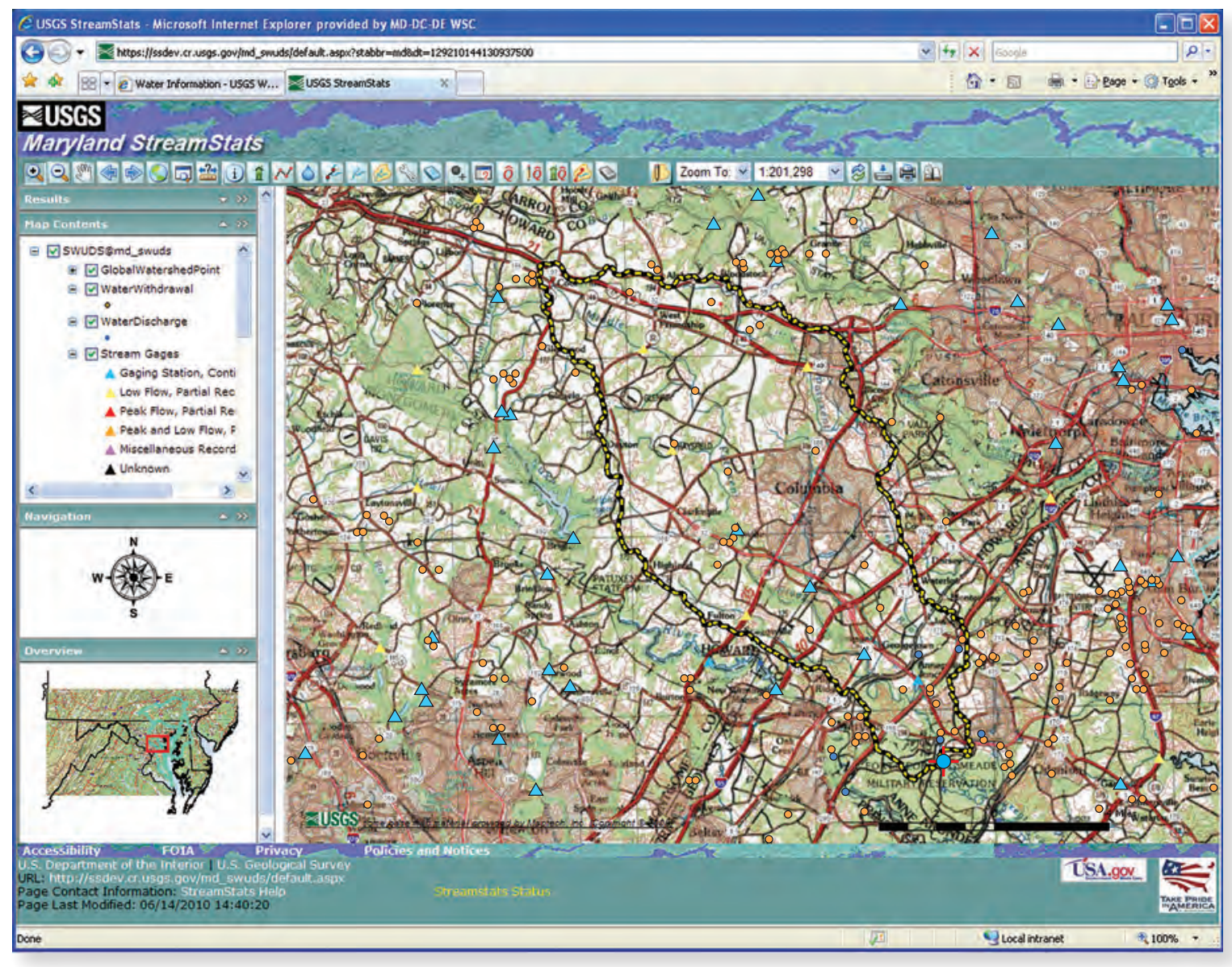

Figure 6. Example watershed delineation (black and yellow line) for an ungaged site in Maryland StreamStats, showing upstream data-collection stations (triangles), water withdrawals (small orange dots), and water discharge locations (small blue dots). (The location of the ungaged site is shown as a large blue dot with red crosshairs along the southern edge of the delineated boundary.)

Water-Use Report
Withdrawal-Discharge Summary Report for 2005
[values are in million gallons per day except the annual sum is in million gallons]
\begin{tabular}{|l|r|r|r|r|r|r|r|r|r|r|r|r|r|r|r|r|}
\hline Totals & January & February March April & May & June & July & August September & October November December Annual mean Annual sum \\
\hline Withdrawals & 2.612 & 2.657 & 2.915 & 2.559 & 2.719 & 3.102 & 1.789 & 1.53 & 1.284 & 2.896 & 2.686 & 2.389 & 2.4265 & 885.676 \\
\hline Discharges & 0.0657 & 0.0557 & 0.0746 & 0.0657 & 0.0557 & 0.0553 & 0.0557 & 0.0457 & 0.047 & 0.0457 & 0.0457 & 0.0557 & 0.0557 & 0.6682 \\
\hline Net & -2.5463 & -2.6013 & -2.8404 & -2.4933 & -2.6633 & -3.0467 & -1.7333 & -1.4843 & -1.237 & -2.8503 & -2.6403 & -2.3333 & -2.4247 & -885.0078 \\
\hline
\end{tabular}

Figure 7. Example water-use summary report for the ungaged site shown in figure 6. 


\section{Estimating Streamflow Statistics for Ungaged Sites Based on the Flows at Nearby Streamgages}

The process for obtaining estimates of flow statistics for an ungaged site based on the known flows for nearby streamgages is similar to the process for obtaining estimates from regression equations. Users still need to locate sites of interest and delineate the drainage boundaries. The Generate Flows Based on Similar Gages tool is then used to obtain the flow estimates. When this tool is used, StreamStats searches upstream and downstream along the stream network to locate nearby streamgages. Streamgages will be used as the basis for estimating streamflow statistics for the ungaged site if the drainage area for the ungaged site is within 0.5 and 1.5 times the drainage area for the streamgage. This range of drainagearea ratios can vary by state. The streamflow statistics and the drainage area for the station with the drainage-area ratio closest to one will be retrieved from a database and the flow per unit area will be computed for each statistic. These flows per unit area will then be multiplied by the drainage area for the ungaged site to obtain the estimates. If another station in the opposite direction along the stream network also has a drainage-area ratio within the specified limits, then it also will be used to estimate streamflow statistics for the ungaged site. If both an upstream and a downstream station were used for estimation, then final estimates will be determined by weighting the upstream and downstream estimates by a process explained in Ries and Dillow (2006). Water-use summaries are not provided in the outputs produced from this process.

\section{Estimating Streamflow Statistics for Ungaged Sites in the Bynum Anomaly}

Carpenter and Hayes (1996) suggested estimating lowflow statistics for ungaged sites in the Bynum Anomaly based on the average of the flows per unit area for data-collection stations within the area. Reports that contain descriptive information, and previously published basin characteristics and streamflow statistics for four stations in the Bynum Anomaly can be obtained from StreamStats by following the instructions provided in the "Streamflow Statistics for DataCollection Stations" section. For convenience, all previously published streamflow statistics, except for peak-flow statistics, are presented in table 3 along with the average values. The statistics in table 3 are in cubic feet per second per square mile, and were determined by dividing the previously published statistics by the drainage area for the station. Peak-flow statistics were not included for the stations in table 3 because regression equations are available to estimate peak-flow statistics for ungaged sites in the Bynum Anomaly. To obtain estimates of other streamflow statistics for an ungaged site within the Bynum Anomaly, first use StreamStats to delineate the drainage basin for the ungaged site and determine its drainage area. Next, multiply the drainage area for the ungaged site by the average values of flow per unit area in the right-hand column of table 3 to determine the corresponding flow estimate for the ungaged site. The Basin Characteristics tool or the Estimate Flows using Regression Equations tool may be used to obtain the drainage area and other basin characteristics for the ungaged site. The Estimate Flows using Regression Equations tool will provide the peak-flow estimates and the water-use summary for the ungaged site.

Carpenter and Hayes (1996) originally suggested three stations for use in estimating streamflow statistics in the Bynum Anomaly, the streamgage at Bynum Run at Bel Air, MD (01581500) and the low-flow partial-record stations James Run at Bush, MD (01581650) and Bynum Run at Bush, MD (01581600). Since Carpenter and Hayes' report was published, another streamgage was established within the Bynum Anomaly, Bynum Run near Bel Air, MD (01581000). Statistics for all four stations are provided in table 3 . These statistics are subject to change whenever new streamflow statistics are published for the stations.

\section{Limitations for Estimates of Streamflow and Water Use for Ungaged Sites}

Estimates of streamflow statistics that are obtained from regression equations are based on the assumption of natural flow conditions at the ungaged site. If human activities such as dam regulation, water withdrawals, or return flows substantially affect the timing, magnitude, or duration of flows at a selected site and estimates of actual flows are desired, then the regression-equation estimates provided by StreamStats should be adjusted by the user to account for these activities. StreamStats for Maryland has been modified to provide summaries of withdrawals and return flows, but it does not account for the effects of dam regulation of flow. The water-use summaries also do not consider the fate of the water once it is withdrawn from a particular location. Part or all of the water may be exported from the basin or lost to consumptive uses. Alternately, much of the withdrawn water may be returned to the basin through individual septic systems or through municipal water-treatment-plant discharges.

StreamStats can be used to obtain regression-equation estimates of streamflow statistics for USGS data-collection stations. Users should understand that there are errors associated with estimates determined from available data for the stations as well as estimates determined from regression equations, and some disagreement between the two sets of estimates is expected. If the flows at the stations are affected by human activities, then users should not assume that the differences between the data-based estimates and the regression-equation estimates are equivalent to the effects of human activities on streamflow at the stations.

When StreamStats is used to obtain regression-equation estimates for sites with basin characteristics outside the ranges of those for the sites used to develop the regression equations, 
Table 3. Previously published streamflow statistics for streamgages and low-flow partial-record stations, and average values in the Bynum Anomaly area of Piedmont subregion C.

[Values are in cubic feet per second per square mile, except daily flow years are in years.]

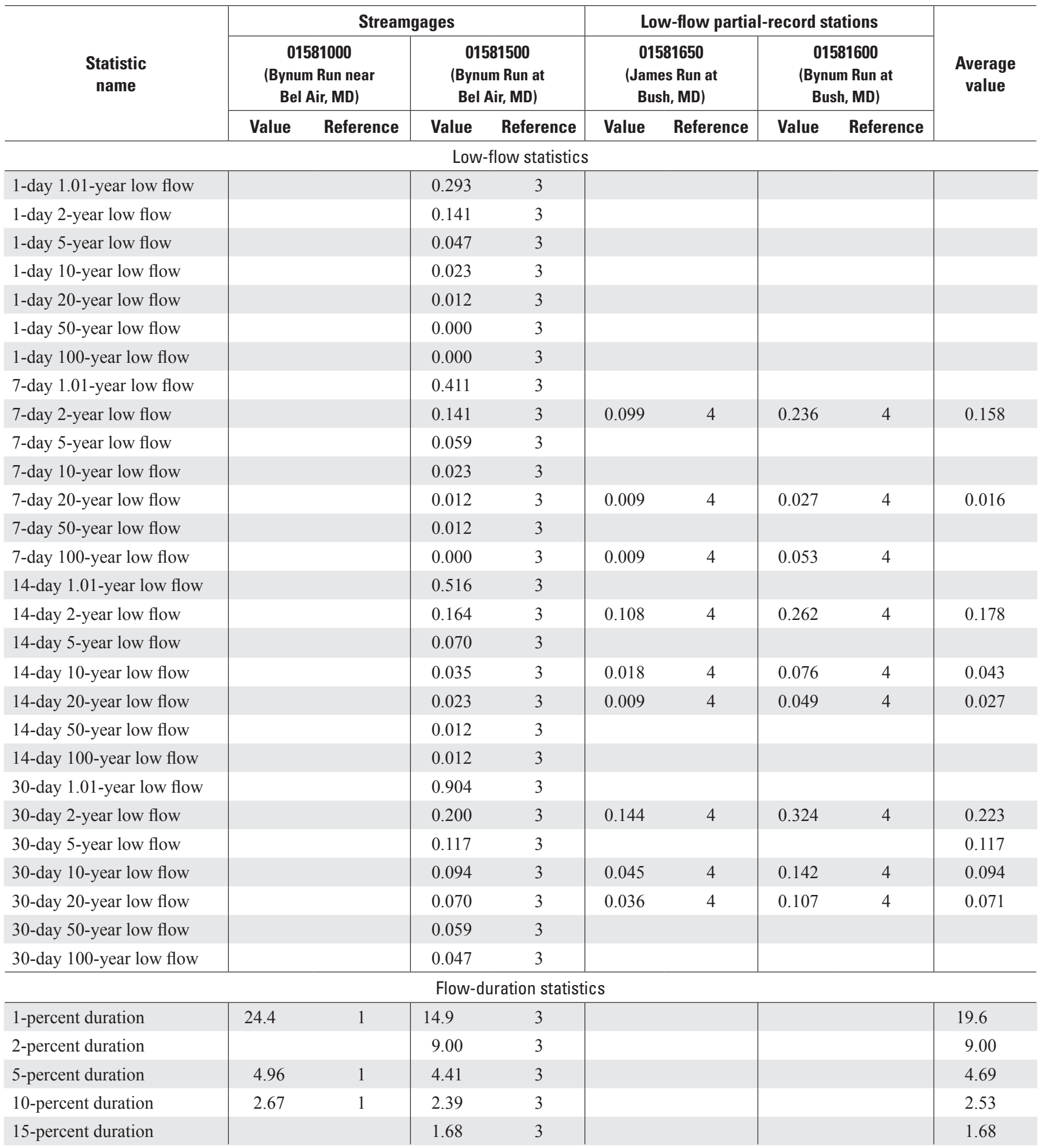


Table 3. Previously published streamflow statistics for streamgages and low-flow partial-record stations, and average values in the Bynum Anomaly area of Piedmont subregion C.-Continued

[Values are in cubic feet per second per square mile, except daily flow years are in years.]

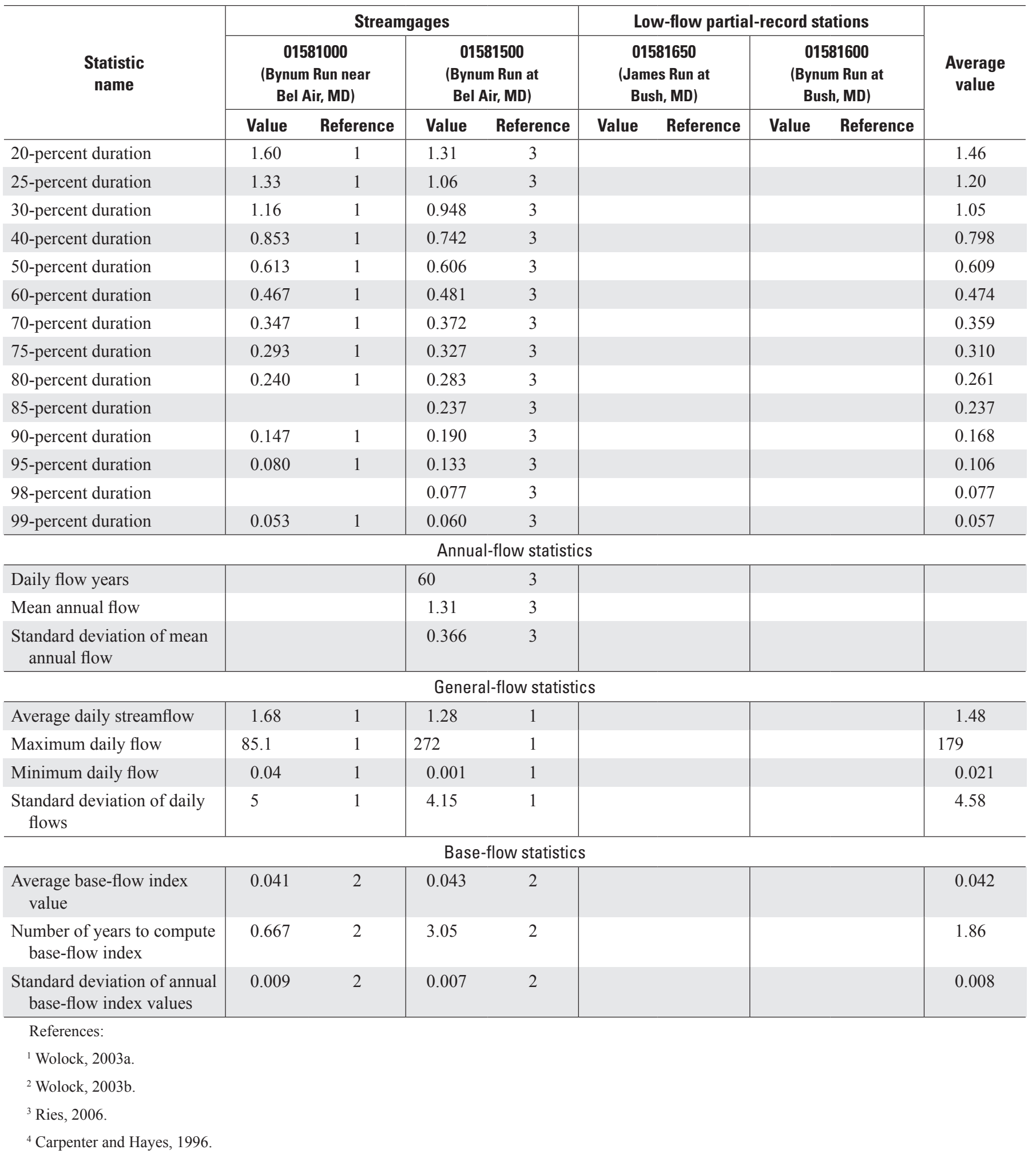


the estimates are extrapolated. Errors associated with these estimates are unknown and may be very large. StreamStats provides a warning when extrapolation occurs. Errors associated with estimates obtained by use of the methods recommended in this report for ungaged sites within the Bynum Anomaly also are unknown.

When the Generate Flows Based on Similar Gages tool is used to obtain estimates for ungaged sites, StreamStats users can specify whether to include only stations with natural flow conditions in the analysis or to also include stations that are affected by flow regulations. This decision must be made carefully. If users choose to allow use of regulated stations, then they should consider how the effects of regulation could change between the streamgage and the ungaged site. If a regulated station is downstream from the ungaged site, for example, it is possible that the stream is not affected by regulation at the ungaged site, and therefore the streamflow statistics estimated on the basis of the flow per unit area at the station will not be representative of the flow conditions at the ungaged site. Conversely, if the regulated station is upstream from the ungaged site, streamflow from tributaries entering between the station and the ungaged site may dampen the effects of the regulation at the station and cause the estimated streamflow statistics to be unrepresentative of conditions at the ungaged site.

\section{Summary and Conclusions}

Approximately 25,000 new households and thousands of new jobs will be established in an area that extends from southwest to northeast of Baltimore, Maryland, as a result of the Federal Base Realignment and Closure (BRAC) process, with consequent new demands on the water resources of the area. The Maryland Department of the Environment (MDE), which is responsible for issuing permits for water withdrawals and wastewater discharges throughout Maryland, needs to understand the natural availability of the water resources in relation to current and requested water withdrawals and wastewater discharges as a basis for making good permitting decisions in BRAC-affected areas. The U.S. Geological Survey (USGS), in cooperation with the MDE, has extended the area of implementation and added functionality to an existing map-based Web application named StreamStats to provide an improved tool for planning and managing the water resources in the BRAC-affected areas. StreamStats previously was implemented for only a small area surrounding Baltimore, Maryland, and it has now been extended to cover all BRACaffected areas in Maryland.
StreamStats is a map-based Web application that allows users to obtain information on streamflow availability at USGS data-collection stations and at user-selected ungaged sites. Prior to completion of the study that is described in this report, StreamStats was available only in the GunpowderPatapsco hydrologic accounting unit in Maryland. Users could obtain descriptive information and previously published basin characteristics and streamflow statistics for datacollection stations. Users also could obtain drainage-basin delineations, computed basin characteristics, and estimated streamflow statistics for ungaged sites in the implemented area. StreamStats has now been implemented in the entire area that is expected to be affected by the BRAC process. This area includes the Chester-Sassafras, Lower Susquehanna, Gunpowder-Patapsco, Severn, and Patuxent hydrologic accounting units in Maryland. In addition, StreamStats was modified to provide summaries of water-use activities for userselected sites in the BRAC area. This was accomplished by creating a link between StreamStats and the USGS SWUDS water-use database.

StreamStats can provide estimates of peak-flow frequency statistics, such as the 1-percent probability (100-year recurrence interval) flood, and low-flow frequency statistics, such as the 7-day, 10-year low flow, for ungaged sites by solving previously published regression equations. These equations were developed from regression analyses using basin characteristics that were measured manually as the explanatory variables, whereas StreamStats determines the basin characteristics from digital datasets. In testing, it was determined that StreamStats was not able to accurately reproduce the manual measurements of percentage of forest cover that were used as an explanatory variable in the peakflow frequency equations. The peak-flow frequency equations for the Piedmont hydrologic region are much less sensitive to the measured values of percentage of forest cover than the equations for the Western Coastal Plain hydrologic region. As a result, the peak-flow frequency equations were made available to StreamStats users in the Piedmont hydrologic region but not in the Western Coastal Plain hydrologic region. The standard errors of prediction for estimates of peak flow provided by StreamStats are likely somewhat larger than the previously published standard errors of prediction, which ranged from 35 percent for the 10-percent probability (10-year recurrence interval) flood to 52 percent for the 0.2 percent probability (500-year recurrence interval) flood.

Previously published low-flow frequency equations were implemented in StreamStats for subregions A through D of the Eastern Piedmont hydrologic region. Standard errors of prediction for the equations ranged from 8.9 percent for the 
30-day, 2-year low flow in subregion $C$ to 55 percent for the 7-day, 20-year low flow in subregion B. Equations were not available for a small area within Eastern Piedmont subregion $\mathrm{C}$ named the Bynum Anomaly, or for the Southern hydrologic region, which roughly corresponds with the part of the Coastal Plain Physiographic Province that is along the western shore of the Chesapeake Bay. This report provides a semi-automated method for obtaining estimates of low-flow statistics in the Bynum Anomaly, but no method is available for estimating low-flow statistics in the Southern hydrologic region.

Information on water discharges and conveyances was added to the Site-Specific Water-Use Data System (SWUDS) for this study. Only water-withdrawal information was available beforehand. The additional information allowed tracking of water from the point of withdrawal to the point of discharge. Data from several state databases and a commercial database were used to fully document the water conveyances. Water withdrawal and discharge data were extracted from SWUDS and entered into the SWUDS Data Warehouse, a Microsoft Access database that was created for this study to facilitate linkage of the water-use data with StreamStats. A Web service was then created that would accept a basin delineation from StreamStats, overlay it on a Geographic Information System layer of withdrawals and discharges, and send a summary of the withdrawals and discharges back to the StreamStats user. This linkage of StreamStats with water-use information from SWUDS should enable Maryland regulators and planners to make more informed decisions on the use of water resources in the BRAC area, and is transferrable to other geographic areas.

\section{Acknowledgments}

The authors would like to thank the MDE for its support of this work. In particular, John Grace and Patrick Hammond provided perspective on the needs of the MDE for streamflow statistics and how the MDE uses that information. The MDE also provided feedback on design of the StreamStats wateruse summaries, and they provided other guidance throughout the project. In addition, the authors acknowledge hydrologist Michael Koterba, of the USGS, for providing some of the information used to describe the study area in this report. Finally, the authors appreciate the help of USGS employees Valerie Gaine, Gloria Wilson, Betzaida Reyes, and Timothy Auer, for providing editing, illustrations preparation, and final layout of this report.

\section{References Cited}

Anne Arundel County, 2010, BRAC/Growth at Fort Meade working plan, 35 p., accessed February 18, 2010 at http:// www.aacounty.org/BRAC/Resources/BRAC_WorkingPlan. $p d f$.

Bolton, D.W., Gerhart, J.M., and Kasraei, S., 2009, Sustainability of water resources in the fractured-rock area of Maryland: U.S. Geological Survey Fact Sheet 20093009, 2 p. (Available at http://pubs.usgs.gov/fs/2009/3009/)

Carpenter, D.H., and Hayes, D.C., 1996, Low-flow characteristics of streams in Maryland and Delaware: U.S. Geological Survey Water-Resources Investigations Report 94-4020, 113 p., accessed May 26, 2009 at http://pubs. er.usgs.gov/usgspubs/wri/wri944020.

Defense Base Closure and Realignment Commission, 2005, Final Report to the President, accessed May 26, 2009 at http://www.brac.gov/finalreport.html.

Dillow, J.J.A., 1996, Technique for estimating magnitude and frequency of peak flows in Maryland: U.S. Geological Survey Water-Resources Investigations Report 95-4154, 55 p., accessed May 27, 2009 at http://pubs.er.usgs.gov/ usgspubs/wri/wri954154.

Environmental Systems Research Institute, Inc., 2010a, Hydro Data Model, accessed February 17, 2010 at http://resources. arcgis.com/content/hydro-data-model.

Environmental Systems Research Institute, Inc., 2010b, ArcGIS: A complete integrated system, accessed February 17, 2010 at http://www.esri.com/software/arcgis/index.html.

Fenneman, N.M., 1938, Physiography of the Eastern United States: New York, McGraw-Hill, 714 p.

Gesch, D., Evans, G., Mauck, J., Hutchinson, J., and Carswell, W.J., Jr., 2009, The National Map-Elevation: U.S. Geological Survey Fact Sheet 2009-3053, 4 p., accessed September 14, 2009 at http://pubs.usgs.gov/fs/2009/3053/.

Maidment, David, 2002, Arc Hydro: GIS for Water Resources: Redlands, California, Environmental Systems Research Institute, Inc., 224 p.

Maryland Department of the Environment, 2009, Water Management Permits, accessed May 25, 2009 at http://www. mde.maryland.gov/Permits/WaterManagementPermits/ index.asp. 
Maryland Department of Planning, 2006, Base Relocation and Closure (BRAC) Report, 146 p., accessed February 18, 2010 at http://www.mdp.state.md.us/msdc/military/Report/ Main_text.pdf.

Microsoft Corp., 2009, Getting started with Visual Basic, accessed September 9, 2009 at http://msdn.microsoft.com/ en-us/vbasic/bb466159.aspx.

National Resources Conservation Service, 2009, Information about Hydrologic Units and the Watershed Boundary Dataset (WBD), accessed September 14, 2009 at http:// www.ncgc.nrcs.usda.gov/products/datasets/watershed/ datainfo.html.

Ries, K.G., III, 2006, Selected streamflow statistics for streamgaging stations in northeastern Maryland, 2006: U.S. Geological Survey Open-File Report 2006-1335, 24 p. (Available at http://pubs.usgs.gov/of/2006/1335/).

Ries, K.G., III, and Dillow, J.J.A., 2006, Magnitude and frequency of floods in Delaware: U.S. Geological Scientific Investigations Report 2006-5146, 59 p. (Available at http:// pubs.usgs.gov/sir/2006/5146/).

Ries, K.G., III, Guthrie, J.D., Rea, A.H., Steeves, P.A., and Stewart, D.W., 2008, StreamStats: A water resources web application: U.S. Geological Survey Fact Sheet 2008-3067, 6 p., accessed May 27, 2009 at http://pubs.usgs.gov/ $f_{S} / 2008 / 3067 /$.

Seaber, P.R., Kapinos, F.P., and Knapp, G.L., 1987, Hydrologic unit maps: U.S. Geological Survey Water Supply Paper 2294, 63 p., accessed August 16, 2009 at http://pubs.usgs.gov/wsp/wsp2294/.
Simley, J.D., and Carswell, W.J., Jr., 2009, The National Map-Hydrography: U.S. Geological Survey Fact Sheet 2009-3054, 4 p., accessed September 14, 2009 at http:// pubs.usgs.gov/fs/2009/3054/.

Soeder, D.J., Raffensperger, J.P., and Nardi, M.R., 2007, Effects of withdrawals on ground-water levels in Southern Maryland and the adjacent Eastern Shore, 1980-2005: U.S. Geological Survey Scientific Investigations Report 2007-5249, 82 p. (Available at http://pubs.usgs.gov/ $\operatorname{sir} / 2007 / 5249 /)$.

Spencer, T.A., Phelan, D.J., Olsen, L.D., and Lorah, M.M., 2001, Ground-water and surface-water quality data for the West Branch Canal Creek area, Aberdeen Proving Ground, Maryland, November 1999-May 2001: U.S. Geological Survey Open-File Report 01-420, 220 p.

Wolock, D.M., 2003a, Flow characteristics at U.S. Geological Survey streamgages in the conterminous United States: U.S. Geological Survey Open-File Report 03-146, digital dataset, accessed January 21, 2009 at at http://water.usgs. gov/lookup/getspatial? qsitesdd.

Wolock, D.M., 2003b, Base-flow index grid for the conterminous United States: U.S. Geological Survey Open-File Report 03-263, digital dataset, accessed January 21, 2009 at http://water.usgs.gov/lookup/getspatial?bfi48grd. 
Prepared by USGS West Trenton Publishing Service Center. Edited by Valerie M. Gaine.

Graphics and layout by Timothy W. Auer.

For additional information, contact:

Kernell G. Ries III, Office of Surface Water

443-498-5617

or Director, MD-DE-DC Water Science Center

U.S. Geological Survey

5522 Research Park Drive

Baltimore, MD 21228

443-498-5500

or visit the MD-DE-DC Water Science Center Web site at: http://md.water.usgs.gov

or the StreamStats homepage at:

http://streamstats.usgs.gov 
